\title{
EXPERIMENTALWORKS
}

UDC $616.61+577.21$

doi: https://doi.org/10.15407/ubj93.01.051

\section{LEPTIN AND CURCUMIN AFFECT RENAL ISCHEMIA-REPERFUSION INJURY VIA MODULATION OF P65 AND BAX GENES EXPRESSION}

\author{
M. M. RAGY $Y^{1}$, M. M. RAMZY'四 \\ ${ }^{1}$ Physiology Department, Faculty of Medicine, Minia University, Misr-Aswan Road, Egypt; \\ ${ }^{2}$ Biochemistry Department, Faculty of Medicine, Minia University, Misr-Aswan Road, Egypt; \\ e-mail:maggiemaher24@gmail.com
}

Received: 01 June 2020; Accepted: 17 December 2020

Ischemia and reperfusion are natural steps during kidney transplantation, and ischemia-reperfusion injury is a critical condition in which physicians must preserve organ function and control cell damage. As leptin is thought to play an important role in the regulation of the immune system and inflammation and curcumin is a potent anti-fibrotic agent, both agents are promising to have therapeutic impact on renal damage. The present study was designed to evaluate the effects of leptin and curcumin on renal ischemia-reperfusion injury. Forty adult male albino rats were divided into four groups: control; ischemia-reperfusion $(I / R)$, leptintreated (leptin was injected intraperitoneally at a dose $100 \mu \mathrm{g} / \mathrm{kg}$ for 3 days prior to ischemia) and curcumintreated (curcumin was given orally at a dose of $50 \mathrm{mg} / \mathrm{kg} /$ day for 5 days before ischemia). All rats were sacrificed 24 hours after reperfusion. Serum urea and creatinine, renal malondialdehyde and total antioxidant capacity were measured. Renal TNF- $\alpha$ was assayed by ELISA and P65 and Bax mRNA expression were determined using RT-PCR. Our results demonstrated a significant increase in P65 and Bax mRNA expression after renal ischemia-reperfusion injury compared to control group. Both leptin and curcumin prevented oxidative damage of the renal tissues as they lowered MDA and nitric oxide levels, increased antioxidant capacity and decreased TNF- $\alpha$ level. It was shown that protective leptin and curcumin effect against kidney IR-induced oxidative injury was associated with a down-regulation of P65 and Bax expression. These results show that ischemia-reperfusion leads to renal damage and also they reveal that both leptin and curcumin have protective implications which may be promising agents for avoiding various adverse effects.

Keywords: Ischemia-reperfusion, kidney, Bax, P65, curcumin, leptin.

$\mathrm{R}$ enal ischemia-reperfusion (IR) injury is a critical clinical issue in kidney transplantations, cardiovascular surgery, shock and burn and it is the major cause of morbidity and mortality during the perioperative period [1].

Ischemia-reperfusion injury may be related to the synthesis of proinflammatory mediators, production of oxygen free radicals, and cell apoptosis [2]. The mechanisms that lead to the synthesis of proinflammatory and apoptotic mediators have been in- vestigated in recent years [3]. Tumor necrosis factor alpha $(\mathrm{TNF}-\alpha)$ is an important extracellular initiator of IR-induced inflammation and apoptosis. It activates a group of proteins called nuclear factor-kappa $\beta$ which regulates the inflammatory and apoptotic process [4].

NF-kB family members consist of five transcription factors in mammalians: RelA/p65, RelB, c-rel, NFkB1/p50 and NF-kB2/p52 [5]. These transcription factors form homo- or hetero-dimers

(C) 2021 Ragy M. M., Ramzy M. M. This is an open-access article distributed under the terms of the Creative Commons Attribution License, which permits unrestricted use, distribution, and reproduction in any medium, provided the original author and source are credited. 
to regulate different genes by binding to its target sequence on DNA which known as the $\mathrm{kB}$ sites. NF-kB has been linked to various forms of experimental and human renal injury [6].

Furthermore NF- $\kappa B$ plays a key role in the immune response so abnormal regulation of NF- $\kappa \mathrm{B}$ has been associated with inflammation, cancer and inappropriate immune development. Moreover it has a central role in the expression of proinflammatory genes, which are involved in the development of progressive renal inflammatory disease [4].

During the apoptotic process, early intracellular events occur including mitochondrial changes which are mediated by members of the $\mathrm{Bcl}-2$ family. Bax is the first identified pro-apoptotic member of Bcl-2 family [7]. Following a death stimulus, the pro-apoptotic family members, BAX and BAK proteins form homo- and hetero-oligomers affecting mitochondrial outer membrane permeability and the release of inter-membrane space proteins such as Cytochrome c and activation of the apoptotic pathway [8].

Leptin is adipocyte-derived hormone, plays important roles in physiological processes, including fat storage and metabolic status which are linked to satiety, energy homeostasis, and reproduction in all vertebrates [9]. The renal effect of leptin remains controversial and it differs according the dose, time and administration route. For example, leptin involvement in chronic kidney disease and in obesityrelated glomerulopathy is characterized by hyperleptinemia [10]. However, it exhibits cytoprotective effects on renal sepsis [11].

Curcumin is derived from the plant Curcuma longa called turmeric. These compounds play an important role in diseases prevention and health maintaining, in addition to its therapeutic effects such as anti-inflammatory, anti-tumor and anti-oxidant activities [12]. Curcumin may provoke some protection against chronic kidney disease and progression to end-stage renal failure through affecting inflammatory enzymes and molecules which lead to chronic kidney disease [13] but, the evidence is still under investigation.

A number of studies have been performed in experimental models of renal disease and the effect of exogenous leptin and curcumin on renal damage has not yet been fully defined so the current study was designed to examine the renal changes happened as a result of ischemia-reperfusion injury in rat model and the effect of leptin and curcumin on pro-inflammatory and pro-apoptotic processes in this model. This may underlie the complexity of this condition and the potential targets for therapeutic intervention.

\section{Materials and Methods}

Establishment of renal ischemia-reperfusion model. The study was approved by the institutional ethical committee of Faculty of Medicine - Minia University. Rats were fasted for $12 \mathrm{~h}$ before surgery. After anesthesia with intraperitoneal injection of xylazine $(10 \mathrm{mg} / \mathrm{kg}$ ) and ketamine (50 mg/kg bw), abdominal hair was removed and an incision was made on abdomen along the mediventral line to open abdominal cavity. The anesthetized rat was placed on a heating pad to maintain the rectal temperature constant $\left(37^{\circ} \mathrm{C}\right)$ throughout the surgery. Renal capsule was bluntly separated to separate the kidneys. Renal pedicles were obstructed for 45 min with arterial clamps. After 45 min of blockage, the clamps were taken away, and the kidneys were examined to endure reperfusion for $60 \mathrm{~min}$ [13].

Animals. Adult male albino rats weighed about 180: 200 g were used throughout this study. All animals received humane care according to the criteria outlined in the "Guide for the Care and Use of Laboratory Animals” prepared by NIH. They were kept at room temperature with natural light/dark cycles for one week to acclaim to the lab environment before inclusion in the study. All rats were provided with normal rat pellet diet (NPD) and tap water ad libitum. The rats were randomly classified into the following four groups (10 rats each): 1 - Control (C) group, both kidneys in rats were separated and exposed for $45 \mathrm{~min}$, but renal pedicles were not clipped. 2 - Ischemia reperfusion group (I/R) group. In I/R group, bilateral renal pedicles were clipped for $45 \mathrm{~min}$, followed by perfusion for $1 \mathrm{~h}$ to establish I/R model. 3 - (I/R) + Leptin treated group: rats received leptin at a dose $100 \mu \mathrm{g} / \mathrm{kg}$. intraperitoneally three consecutive days prior to ischemia [14]. 4 - (I/R) + Curcumin treated group: Rats were treated with orally $50 \mathrm{mg} / \mathrm{kg} /$ day for 5 days before ischemia [15].

Sample collection. All rats in each group were sacrificed by decapitation 24 hours after reperfusion. Sera were collected after blood centrifugation. The clear sera were stored at $-20^{\circ} \mathrm{C}$ for determination of serum urea and serum creatinine (Diamond Diagnostics, Egypt). In all animals, one kidney was divided into two parts; one part was stored at $-80^{\circ} \mathrm{C}$ for RNA extraction and the other part was homogenized for biochemical analysis. 
Analysis of renal homogenates. The excised kidney specimens for biochemical assay were weighed and homogenized separately in potassium phosphate buffer $10 \mathrm{mM} \mathrm{pH}$ (7.4). The ratio of tissue weight to homogenization buffer was $1: 10$. The homogenates were centrifuged and the resulting supernatant was used for measurement of renal malondialdehyde (MDA) and total antioxidant capacity (TAC) according to the manufacturer' instructions (Biodiagnostic, Egypt). Renal tumor necrosis factor was assayed according to rat TNF- $\alpha$ ELISA Kit (Glory Science Co., Ltd, USA). NO was measured by enzymatic colorimetric methods using commercial kits (Biodiagnostic, Egypt).

Real-time PCR for the relative quantification of P65 and Bax mRNA level. Real-time PCR was used for quantitative assessment of P65 and Bax expression in rat renal tissues. Total RNA was extracted from homogenized kidney using RiboZol solution (Amresco, Solon, USA) following the manufacturer's instructions.

cDNAs were synthesized using SensiFAST TM cDNA synthesis Kit (Bioline). cDNA was synthesized at $42^{\circ} \mathrm{C}$ for $15 \mathrm{~min}$ then at $85^{\circ} \mathrm{C}$ for 5 min followed by immediate cooling on ice. Real-time polymerase chain reaction was performed using $10 \mu \mathrm{l}$ of SYBR Green QPCR Mix (SensiFASTTM SYBR ${ }^{\mathrm{T}}$ Lo-ROX Kit, Bioline). The SYBR green data were analyzed with a relative quantification to GAPDH (Glyceraldehyde-3-phosphate dehydrogenase) as reference gene. The sets of primers used were as follows: P65 sense primers, 5' GGCCTCATCCACATGAACTT-3', P65 antisense, 5'-CACTGTCACCTGGAAGCAGA-3, Bax sense primers, 5'-GGAGACACCTGAGCTGACCT-3', Bax antisense primers, 5'-CTCAGCCCATCTTCTTCCAG-3' and GAPDH sense primers: 5'-GTCGGTGTGAACGGATTTG-3' and antisense 5'-CTTGCCGTGGGTAGAGTCAT-3'. The relative expression level of each gene was calculated using the formula $2^{(-\Delta \Delta \mathrm{Ct})}$. Thus, results were graphed as relative expression compared with control group.

Statistical analysis. All data were represented as mean \pm standard error of the mean (mean \pm SEM). Data including P65 and Bax expression were analyzed by one-way analysis of variance (ANOVA) followed by the Bonferroni multiple comparison test. A $P$ value $\leq 0.05$ was considered to indicate statistical significance. SPSS (version 20) was used as analyzing software.

\section{Results and Discussion}

The renal injury markers, serum urea and creatinine were significantly higher in renal ischemia group than that in control group. Adding either leptin or curcumin significantly lower serum urea or creatinine compared to renal ischemia group but can't reach to control level as shown in (Fig. 1)

As shown in Table 1 ischemia-reperfusion group showed significantly higher MDA, NO and TNF- $\alpha$ and significantly lower TAC than the control group. Ischemia-reperfusion + leptin and ischemia-
A

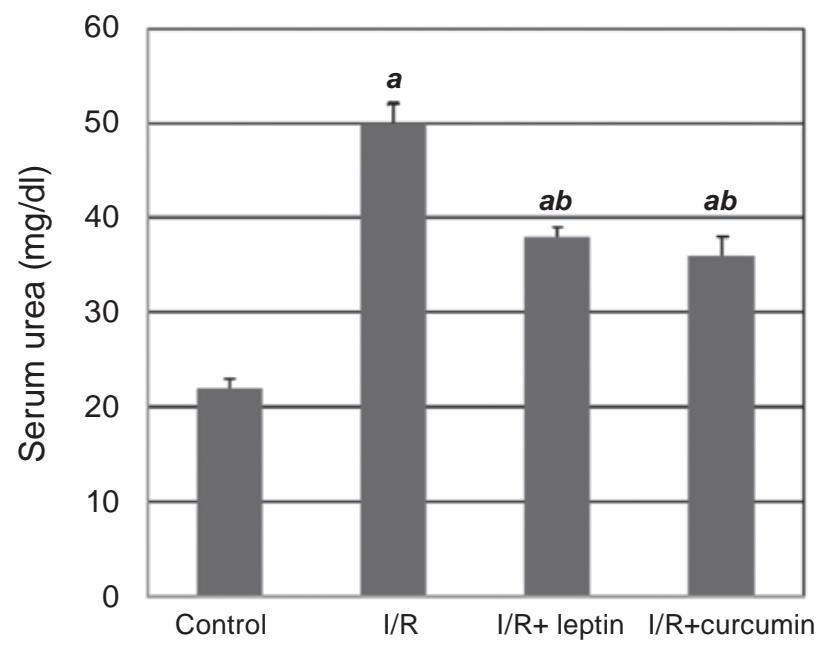

B

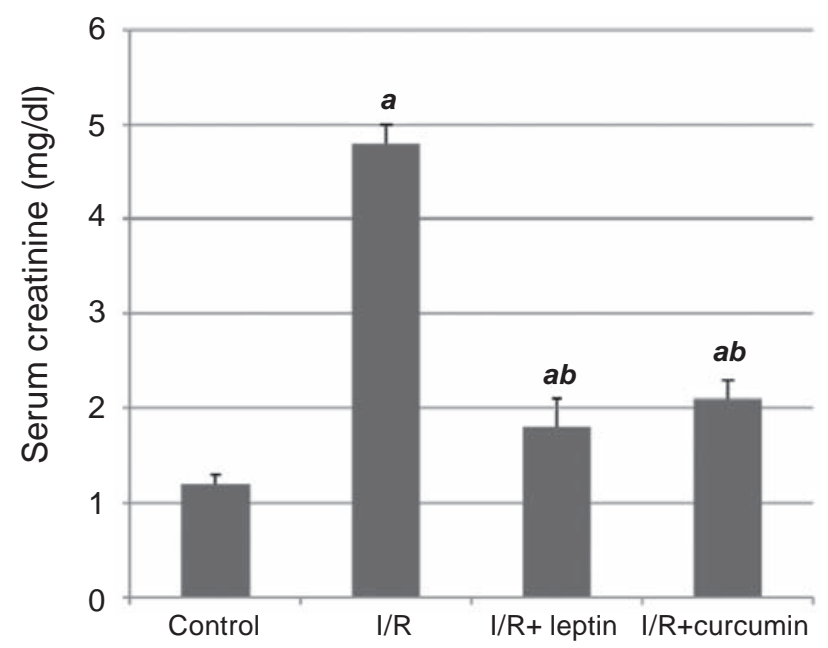

Fig. 1. Changes of serum urea (A) and creatinine (B) in different groups (10 rats each). Data are presented as mean $\pm S E M, a-$ significant from control, $b$ - significant from renal ischemia group $(P<0.05)$ 
Ta b le 1. Effects of ischemia-reperfusion alone or with leptin or curcumin on renal MDA, TAC-, NO (nitrite), and TNF- $\alpha$ levels

\begin{tabular}{l|c|c|c|c}
\hline & Control & I/R & I/R + leptin & I/R +curcumin \\
\hline MDA, nmol/gm & $8.79 \pm 0.39$ & $15.77 \pm 0.36^{\mathrm{a}}$ & $8.61 \pm 0.50^{\mathrm{b}}$ & $7.56 \pm 0.43^{\mathrm{b}}$ \\
TAC, nmol/gm & $1.20 \pm 0.32$ & $0.60 \pm 0.04^{\mathrm{a}}$ & $1.10 \pm 0.25^{\mathrm{b}}$ & $1.30 \pm 0.30^{\mathrm{b}}$ \\
$\mathrm{NO}, \mu \mathrm{mol} / \mathrm{gm}$ & $31.06 \pm 1.16$ & $50.99 \pm 0.55^{\mathrm{a}}$ & $30.66 \pm 0.97^{\mathrm{b}}$ & $32.82 \pm 1.01^{\mathrm{b}}$ \\
TNF- $\alpha, \mathrm{pg} / \mathrm{mg}$ & & & & \\
tissue protein & $17.55 \pm 1.07$ & $35.0 \pm 1.2^{\mathrm{a}}$ & $16.9 \pm 1.2^{\mathrm{b}}$ & $17.0 \pm 0.9^{\mathrm{b}}$ \\
\hline
\end{tabular}

Data are presented as mean \pm SEM. ${ }^{\text {a }}$ Significant from control, ${ }^{\text {bignificant from IR group. Significant level was set at }}$ $P<0.05, n=10$

reperfusion + curcumin groups showed significantly lower MDA, NO and TNF- $\alpha$ and significantly higher TAC than IR group with non-significant change with control.

Relative expression of P65 $m R N A$ by real time $P C R$. Our results demonstrated a highly significant increase in P65 mRNA expression after renal ischemia-reperfusion injury compared to control group $(P=0.001)$. On the other hand, leptin could significant decrease its expression $(P=0.03)$ and curcumin was able to highly significantly decrease its expression $(P=0.001)$. Relative expression in both groups was non-significant compared to control group ( $P=0.08),(P=0.07)$ respectively (Fig. 2$)$.

Relative expression of Bax $m R N A$ by real time $P C R$. Our results reveal that there is highly significant upregulation of pro-apoptotic Bax gene expression in kidney of ischemia-reperfusion group $(P=0.001)$. On the other hand, curcumin was able to significantly reduced Bax mRNA level compared

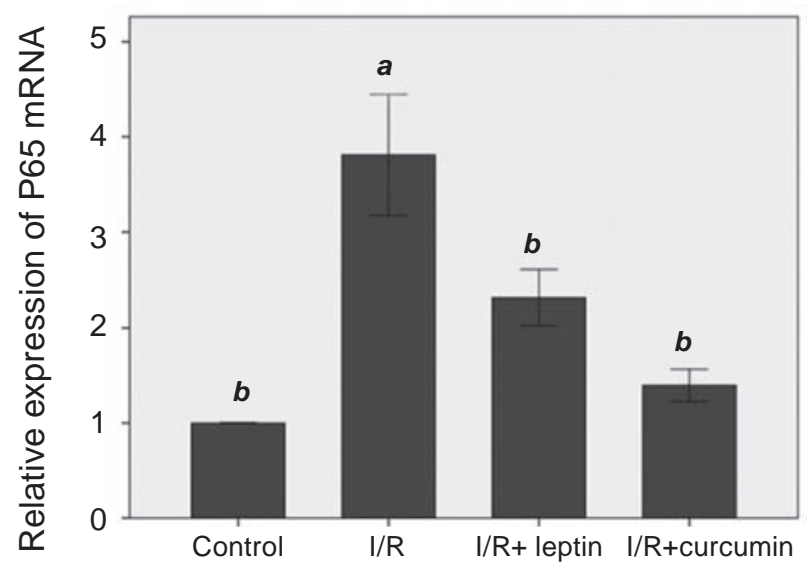

Fig. 2. Relative expression of P65 mRNA in study groups (10 rats each). Data are presented as mean \pm SEM. ${ }^{a}$ Significant from control, ${ }^{b}$ significant from $I / R$ group. Significant level was set at $P<0.05$ to $\mathrm{I} / \mathrm{R}$ group $(P=0.001)$ reaching to non-significant level compared to control group $(P=0.16)$ while leptin decreased its expression $(P=0.001)$ but still significantly higher than control group (Fig. 3).

Ischemia-reperfusion injury is associated with serious multiple-organs dysfunctions including brain, heart, gastrointestinal and systemic inflammatory response syndrome [16].

Ischemia-reperfusion injury in the kidney is used as a model of acute renal injury, which is associated with high mortality rate. Previous studies have described the related factors such as systemic inflammation induced by inflammatory mediators and apoptosis [17]. Inflammation is a physiological response that mediates tissue repair after injury which linked to the pathogenesis of IR-induced acute renal injury [18].

Understanding the mechanism of ischemiareperfusion injury may provide a strong approach for injury prevention and for novel therapeutic op-

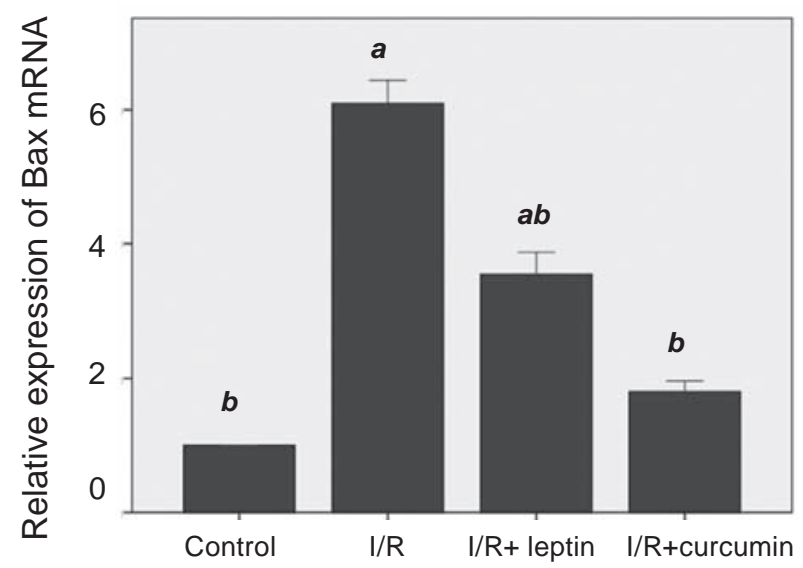

Fig. 3. Relative expression of Bax mRNA in study groups (10 rats each). Data are presented as mean \pm SEM. ${ }^{a}$ Significant from control, ${ }^{b}$ significant from $I / R$ group. Significant level was set at $P<0.05$ 
portunities. In the present work, ischemia-reperfusion produced renal damage manifested by significant increase in serum urea and creatinine levels. In addition, it produced a significant increase in renal MDA, NO and TNF- $\alpha$ with subsequent decreased in of TAC as compared with the control. The generation of reactive oxygen species (ROS) causes oxidative stress which promotes endothelial dysfunction, local inflammatory responses and DNA damage [19]. Ischemia-reperfusion (I/R) injury of both brain and heart has common mechanisms represented by oxidative stress [20].

Activation of NF- $\mathrm{BB}$ promotes pro-inflammatory cytokines including tumour necrosis factor (TNF)- $\alpha$, interleukins (ILs) and nitric oxide (NO) which may finally cause renal damage [4]. This may explain the upregulation of P65 mRNA and pro-apoptotic, Bax gene expression after IR injury which may be a consequence of NF-kB activation. As TNF- $\alpha$ activates the mitochondrial apoptosis pathway and results in apoptosis of renal tubule cells by increasing the expression of Bax gene [21]. This was similar to previous study which revealed the effect of NF-kB in folic acid-induced renal inflammation which was evidenced by a significant increase in the expression of P65 as well as over-expression of Bax gene [5]. Also TNF- $\alpha$ and NF- $\kappa B$ levels were both increased in the cisplatin-induced nephrotoxicity [22]. Moreover pretreatment with NF- $\kappa \mathrm{B}$ inhibitor significantly decreased TNF- $\alpha$ gene expression [23]

Interestingly our results revealed that leptin could attenuate nephrotoxic effects of I/R injury as it decreased MDA, NO and TNF- $\alpha$ and increased TCA in renal tissue, this is in agree with previous study which showed that leptin decreases intestinal IR injury [24]. Furthermore, leptin has been considered an important factor for treating brain ischemia/ reperfusion injury [25] as it has an anti inflammatory effect through inhibiting the expression of tumor necrosis factor (TNF) $\alpha$, IL- 6 , IL-1 $\beta$ and increasing the expression of IL-10 [26].

On assessment of P65, leptin could significantly decrease its mRNA expression and could downregulate the expression of $B a x$ gene in renal tissue in a significant way and although previously leptin caused no significant change in Bax mRNA expression in pancreatic tissue but when Bax protein expression was analyzed by Western blotting, it was found that incubation with leptin caused a significant 28\% decrease [27]. Furthermore, leptin enhanced the nuclear translocation of p50 and p65 in cortical neu- rons with down-regulation of Bax expression [28]. Moreover, it was demonstrated that leptin represses BAX expression at the transcriptional level in placental cell line [29] supporting that ischemic preconditioning can protect ischemia-reperfusion renal damage possibly by decreasing Bax expression and increasing Bcl-2 expression [30].

In the current work, Curcumin has protective effect against $\mathrm{I} / \mathrm{R}$ renal damage through antioxidant effects by reduction renal (MDA, NO \& TNF- $\alpha$ ) with elevation in renal TAC compared with IR group. Curcumin has a beneficial effect in treatment of various kidney diseases such as diabetic nephropathy [31], chronic renal failure [32, 33] and nephrotoxicity [34-36]. Furthermore, it could serve as a therapeutic agent for glomerulonephritis [37] as it significantly attenuated both renal dysfunction and oxidative stress, thereby presenting its potential to treat diabetic nephropathy [31, 38, 39]

Although a clinical trial's in human suggests that increase consumption of curcumin may increase risk of renal stones development in susceptible individuals [40]. However a previous research showed that the antioxidant effect of curcumin was able to decrease oxidative stress and lipid peroxidation caused by calcium stones [41].

Our results demonstrated that curcumin could highly significantly decrease the expression of P65 subunit (the active subunit of NF-kB). This in agree with a previous study which showed that curcumin prevented glomerular, interstitial, tubular epithelial and endothelial cellular damage by decreasing of iNOS and p65 expression and serum nitric oxide levels [42].

It was shown that the anti-inflammatory effects of curcumin is linked to down-regulation of the expression of NF-kB-regulated gene, including COX-2, MMPs, Bax, and caspase-3 [43]. This was in agree with our results as curcumin could decrease the expression of bax gene in renal tissue. Although curcumin can both stimulate and inhibit apoptotic signaling, however, the curcumin effects on various cells depend on the concentration and the time of used treatment [44, 45].

Ghosh and his collagues [46] showed that curcumin treatment improved kidney function in animals with chronic renal failure through antagonizing the effect of TNF- $\alpha$ elicited NF-kB activation and macrophage infiltration; this may reveal that the anti-inflammatory property of curcumin may be responsible for alleviating chronic renal failure. 
Curcumin is able to prevent renal injury through several mechanisms; (A) By the reduction of oxidative stress by preventing the generation of $\mathrm{O}_{2}$ - and scavenging different reactive oxygen species, (B) by preventing the Nrf2 degradation, thus an increase of many anti-oxidant enzymes. (C) by reducing the inflammatory transcription factors such as NF- $\kappa \mathrm{B}$ through inhibition of I $\mathrm{B} \alpha$ kinase (IKK) and TNF- $\alpha$ [47].

Conclusion. The current study suggested that both leptin and curcumin may protect kidney against IR-induced oxidative injury, probably through attenuating oxidative stress which is related to the dysregulation of both pro-inflammatory and proapoptotic processes and that was supported by decreasing TNF- $\alpha$ and down-regulating P65 and Bax expression. Additional research is required to implement applications as clinical treatments in humans.

Conflict of interest. Authors have completed the Unified Conflicts of Interest form at http://ukrbiochemjournal.org/wp-content/uploads/2018/12/ coi_disclosure.pdf and declare no conflict of interest.

Funding. This research was not funded by any organization.

\section{ЛЕПТИН І КУ РКУМІН ВПЛИВАЮТЬ НА УШКОДЖЕННЯ НИРКИ ЗА ІШЕМІЇ-РЕПЕРФУЗІЇ ЧЕРЕЗ РЕГУЛЯЦІЮ ЕКСПРЕСІї ГЕНIВ P65 TA Bax}

\author{
M. M. Ragy ${ }^{1}$, M. M. Ramzy ${ }^{2 冈}$ \\ ${ }^{1}$ Physiology Department, Faculty of Medicine, \\ Minia University, Misr-Aswan Road, Egypt; \\ ${ }^{2}$ Biochemistry Department, Faculty of Medicine, \\ Minia University, Misr-Aswan Road, Egypt; \\ 凶e-mail: maggiemaher24@gmail.com
}

Ішемія та реперфузія - критичний етап трансплантації нирки, під час якого лікарі мають зберегти функцію органів і контролювати пошкодження клітин. Оскільки вважається, що лептин відіграє важливу роль у регуляції імунної системи та запалення, а куркумін $є$ потужним антифібротичним засобом, обидва агенти можуть бути перспективними в терапії ушкодження нирок. У роботі оцінювали вплив лептину та куркуміну на ушкодження нирок, спричинене ішемією-реперфузією. Сорок дорослих самців щурів-альбіносів було поділено на чотири групи: контроль; $з$ ішемією-реперфузією (IP); за введення лептину (внутрішньочеревинно у дозі 100 мкг/кг упродовж 3-х діб перед ішемією); за введення куркуміну (внутрішньочеревинно в дозі 50 мг/кг упродовж 5 діб перед ішемією). Усіх щурів забивали через 24 год після реперфузії. У сироватці крові вимірювали вміст сечовини та креатиніну, у тканині нирки - вміст малонового діальдегіду (MDA) та загальну антиоксидантну активність. Вміст TNF- $\alpha$ в нирках аналізували за допомогою ELISA, експресію мРНК P65 та Bax визначали методом RT-PCR. Спостерігали значне збільшення експресії мРНК P65 та Bax після ішемії-реперфузії нирок порівняно 3 контрольною групою. Як лептин, так і куркумін запобігали окисному ураженню ниркової тканини, оскільки знижували рівень MDA та оксиду азоту, вміст TNF- $\alpha$, підвищували антиоксидантну активність. Показано, що захисний ефект лептину та куркуміну від спричиненого ішемієюреперфузією ураження нирки пов'язаний зі зниженням рівня експресії P65 та Bax. Таким чином, одержані результати продемонстрували, що лептин і куркумін виявляють захисну дію у разі спричиненого IP ушкодженння нирок.

К л юч ов і с лов а: ішемія-реперфузія, нирка, Bax, P65, куркумін, лептин.

\section{References}

1. Jung HS, Joo JD, Kim DW, In JH, Roh M, Jeong JT, Noh SJ, Choi JW. Effect of milrinone on the inflammatory response and NF-kB activation in renal ischemia-reperfusion injury in mice. Korean $J$ Anesthesiol. 2014; 66(2): 136-142.

2. Zhang WZ, Li R, Liu S, Zhang JD, Ning XF, Cai SL. Effects of Renal Ischemic Postconditioning on Myocardial Ultrastructural Organization and Myocardial Expression of Bcl-2/Bax in Rabbits. Biomed Res Int. 2016; 2016: 9349437.

3. Ling Hou L, Chen G, Feng B, Zhang XS, Zheng XF, Xiang Y, Zhao GY, Min WP. Small interfering RNA targeting TNF- $\alpha$ gene significantly attenuates renal ischemia-reperfusion injury in mice. $J$ Huazhong Univ Sci Technolog Med Sci. 2016; 36(5): 634-638.

4. Zhang H, Sun SC. NF- $k B$ in inflammation and renal diseases. Cell Biosci. 2015; 5: 63.

5. Kumar D, Singla SK, Puri V, Puri S. The restrained expression of NF-kB in renal tissue ameliorates folic acid induced acute kidney injury in mice. PLoS One. 2015; 10(1): e115947. 
6. Sanz AB, Sanchez-Niño MD, Ramos AM, Moreno JA, Santamaria B, Ruiz-Ortega M, Egido J, Ortiz A. NFkappaB in renal inflammation. J Am Soc Nephrol. 2010; 21(8): 1254-1262.

7. Oltvai ZN, Milliman CL, Korsmeyer SJ. Bcl-2 heterodimerizes in vivo with a conserved homolog, Bax, that accelerates programmed cell death. Cell. 1993; 74(4): 609-619.

8. Martin SJ, Henry CM, Cullen SP. A perspective on mammalian caspases as positive and negative regulators of inflammation. Mol Cell. 2012; 46(4): 387-397.

9. Poljaroen J, Tinikul Y, Tinikul R, Anurucpreeda P, Sobhon P. Leptin-like immunoreactivity in the central nervous system, digestive organs, and gonads of the giant freshwater prawn, Macrobrachium rosenbergii. Acta Histochem. 2017; 119(5): 569-581.

10. Caszo B, Muslim A, Awang Z, Omar E, Ibrahim E, Singh $H$. The effects of leptin administration on renal function in spontaneously hypertensive rats. Asian $J$ Pharm Clin Res. 2017; 10(1): 108-110.

11. Yan GT, Xue H, Lin J, Hao XH, Zhang K, Wang LH. Leptin protects sepsis-induced renal injury and research for its mechanism. Zhongguo Wei Zhong Bing Ji Jiu Yi Xue. 2006; 18(11): 665-667.

12. Adahoun MA, Al-Akhras MH, Jaafar MS, Bououdina M. Enhanced anti-cancer and antimicrobial activities of curcumin nanoparticles. Artif Cells Nanomed Biotechnol. 2017; 45(1): 98-107.

13. Zhang J, Tang L, Li GS, Wang J. The anti-inflammatory effects of curcumin on renal ischemia-reperfusion injury in rats. Ren Fail. 2018; 40(1): 680-686.

14. Sagiroglu T, Torun N, Yagci M, Yalta T, Sagiroglu G, Oguz S. Effects of apelin and leptin on renal functions following renal ischemia/reperfusion: An experimental study. Exp Ther Med. 2012; 3(5): 908914.

15. Erturk N, Elbe H, Dogan Z, Aktas S, Demirbilek S, Ozturk F. Curcumin prevents renal oxidative stress and tissue damage induced by renal ischemia/ reperfusion in rats. Int Surgery J. 2018; 5(10): 31923197.

16. Wu MY, Yiang GT, Liao WT, Tsai AP, Cheng YL, Cheng PW, Li CY, Li CJ. Current Mechanistic Concepts in Ischemia and Reperfusion Injury. Cell Physiol Biochem. 2018; 46(4): 1650-1667.

17. Markó L, Vigolo E, Hinze C, Park JK, Roël G, Balogh A, Choi M, Wübken A, Cording J, Blasig IE, Luft FC, Scheidereit C, Schmidt-Ott KM, SchmidtUllrich R, Müller DN. Tubular Epithelial NF-кB Activity Regulates Ischemic AKI. J Am Soc Nephrol. 2016; 27(9): 2658-2669.
18. Rabb H, Griffin MD, McKay DB, Swaminathan S, Pickkers P, Rosner MH, Kellum JA, Ronco C. Inflammation in AKI: Current Understanding, Key Questions, and Knowledge Gaps. J Am Soc Nephrol. 2016; 27(2): 371-379.

19. Ornellas FM, Ornellas DS, Martini SV, Castiglione RC, Ventura GM, Rocco PR, Gutfilen B, de Souza SA, Takiya CM, Morales MM. Bone MarrowDerived Mononuclear Cell Therapy Accelerates Renal Ischemia-Reperfusion Injury Recovery by Modulating Inflammatory, Antioxidant and Apoptotic Related Molecules. Cell Physiol Biochem. 2017; 41(5): 1736-1752.

20. Hentia C, Rizzato A, Camporesi E, Yang Z, Muntean DM, Săndesc D, Bosco G. An overview of protective strategies against ischemia/ reperfusion injury: The role of hyperbaric oxygen preconditioning. Brain Behav. 2018; 8(5): e00959.

21. Shu Y, Yang Y, Zhao Y, Ma L, Fu P, Wei T, Zhang L. Melittin Inducing the Apoptosis of Renal Tubule Epithelial Cells through Upregulation of Bax/Bcl2 Expression and Activation of TNF- $\alpha$ Signaling Pathway. Biomed Res Int. 2019; 2019: 9450368.

22. Saral S, Dokumacioglu E, Mercantepe T, Atak M, Cinar S, Saral O, Yildiz L, Iskender H , Tumkaya L. The effect of white tea on serum TNF- $\alpha / \mathrm{NF}-\kappa \mathrm{B}$ and immunohistochemical parameters in cisplatinrelated renal dysfunction in female rats. Biomed Pharmacother. 2019; 112: 108604.

23. Xiao K, Liu C, Tu Z, Xu Q, Chen S, Zhang Y, Wang X, Zhang J, Hu CAA, Liu Y. Activation of the NF- $\kappa \mathrm{B}$ and MAPK Signaling Pathways Contributes to the Inflammatory Responses, but Not Cell Injury, in IPEC-1 Cells Challenged with Hydrogen Peroxide. Oxid Med Cell Longev. 2020; 2020: 5803639.

24. Sarsu SB, Ozokutan BH, Tarakcioglu M, Sarı I, Bağcı C. Effects of Leptin on Intestinal IschemiaReperfusion Injury. Indian J Surg. 2015; 77(Suppl 2): 351-355.

25. Zhang WF, Jin YC, Li XM, Yang Z, Wang D, Cui JJ. Protective effects of leptin against cerebral ischemia/ reperfusion injury. Exp Ther Med. 2019; 17(5): 32823290.

26. Lopez-Rodriguez AB, Mela V, Acaz-Fonseca E, Garcia-Segura LM, Viveros MP. CB2 cannabinoid receptor is involved in the anti-inflammatory effects of leptin in a model of traumatic brain injury. Exp Neurol. 2016; 279: 274-282.

27. Brown JE, Dunmore SJ. Leptin decreases apoptosis and alters BCL-2 : Bax ratio in clonal rodent pancreatic beta-cells. Diabetes Metab Res Rev. 2007; 23(6): 497-502. 
28. Valerio A, Dossena M, Bertolotti P, Boroni F, Sarnico I, Faraco G, Chiarugi A, Frontini A, Giordano A, Liou HC, De Simoni MG, Spano P, Carruba MO, Pizzi M, Nisoli E. Leptin is induced in the ischemic cerebral cortex and exerts neuroprotection through NF-kappaB/c-Rel-dependent transcription. Stroke. 2009; 40(2): 610-617.

29. Toro AR, Maymó JL, Ibarbalz FM, Pérez-Pérez A, Maskin B, Faletti AG, Sánchez-Margalet V, Varone CL. Leptin is an anti-apoptotic effector in placental cells involving p53 downregulation. PLoS One. 2014; 9(6): e99187.

30. Shen S, Zhou J, Meng S, Wu J, Ma J, Zhu C, Deng G, Liu D. The protective effects of ischemic preconditioning on rats with renal ischemiareperfusion injury and the effects on the expression of Bcl-2 and Bax. Exp Ther Med. 2017; 14(5): 40774082.

31. Prabhakar SS. Effects of curcumin in experimental diabetic nephropathy. J Investig Med. 2017; 65(1): 1-6.

32. Abarikwu SO, Durojaiye M, Alabi A, Asonye B, Akiri O. Curcumin protects against gallic acidinduced oxidative stress, suppression of glutathione antioxidant defenses, hepatic and renal damage in rats. Ren Fail. 2016; 38(2): 321-329.

33. Aparicio-Trejo OE, Tapia E, Molina-Jijón E, Medina-Campos ON, Macías-Ruvalcaba NA, LeónContrerasv, Hernández-Pando R, García-Arroyo FE, Cristóbal M, Sánchez-Lozada LG, PedrazaChaverri J. Curcumin prevents mitochondrial dynamics disturbances in early 5/6 nephrectomy: Relation to oxidative stress and mitochondrial bioenergetics. Biofactors. 2017; 43(2): 293-310.

34. He L, Peng X, Zhu J, Liu G, Chen X, Tang C, Liu H, Liu F, Peng Y. Protective effects of curcumin on acute gentamicin-induced nephrotoxicity in rats. Can J Physiol Pharmacol. 2015; 93(4): 275-282.

35. Soliman MM, Baiomy AA, Yassin MH.Molecular and Histopathological Study on the Ameliorative Effects of Curcumin Against Lead Acetate-Induced Hepatotoxicity and Nephrototoxicity in Wistar Rats. Biol Trace Elem Res. 2015; 167(1): 91-102.

36. Topcu-Tarladacalisir Y, Sapmaz-Metin M, Karaca T. Curcumin counteracts cisplatin-induced nephrotoxicity by preventing renal tubular cell apoptosis. Ren Fail. 2016; 38(10): 1741-1748.

37. Jacob A, Chaves L, Eadon MT, Chang A, Quigg RJ, Alexander JJ. Curcumin alleviates immune-complex- mediated glomerulonephritis in factor-H-deficient mice. Immunology. 2013; 139(3): 328-337.

38. Chiu J, Khan ZA, Farhangkhoee H, Chakrabarti S. Curcumin prevents diabetes-associated abnormalities in the kidneys by inhibiting p300 and nuclear factorkappaB. Nutrition. 2009; 25(9): 964-972.

39. Sharma S, Kulkarni SK, Chopra K. Curcumin, the active principle of turmeric (Curcuma longa), ameliorates diabetic nephropathy in rats. Clin Exp Pharmacol Physiol. 2006; 33(10): 940-945.

40. Tang M, Larson-Meyer DE, Liebman M. Effect of cinnamon and turmeric on urinary oxalate excretion, plasma lipids, and plasma glucose in healthy subjects. Am J Clin Nutr. 2008; 87(5): 1262-1267.

41. Ghodasara J, Pawar A, Deshmukh C, Kuchekar B. Inhibitory effect of rutin and curcumin on experimentally-induced calcium oxalate urolithiasis in rats. Pharmacognosy Res. 2010; 2(6): 388-392.

42. Bas M, Tugc V, Kemahli E, Ozbek E, Uhri M, Altug T, Tasci AI. Curcumin prevents shock-wave lithotripsyinduced renal injury through inhibition of nuclear factor kappa-B and inducible nitric oxide synthase activity in rats. Urol Res. 2009; 37(3): 159-164.

43. Buhrmann C, Mobasheri A, Busch F, Aldinger C, Stahlmann R, Montaseri A, Shakibaei M. Curcumin modulates nuclear factor kappaB (NF-kappaB)mediated inflammation in human tenocytes in vitro: role of the phosphatidylinositol 3-kinase/Akt pathway. J Biol Chem. 2011; 286(32): 28556-28566.

44. Loganes C, Lega S, Bramuzzo M, Brumatti LV, Piscianz E, Valencic E, Tommasini A, Marcuzzi A. Curcumin Anti-Apoptotic Action in a Model of Intestinal Epithelial Inflammatory Damage. Nutrients. 2017; 9(6): 578.

45. Yang D, Li Y, Zhao D. Curcumin induces apoptotic cell death in human pancreatic cancer cells via the miR-340/XIAP signaling pathway. Oncol Lett. 2017; 14(2): 1811-1816.

46. Ghosh SS, Massey HD, Krieg R, Fazelbhoy ZA, Ghosh S, Sica DA, Fakhry I, Gehr TWB. Curcumin ameliorates renal failure in 5/6 nephrectomized rats: role of inflammation. Am J Physiol Renal Physiol. 2009; 296(5): F1146-F1157.

47. Trujillo J, Chirino YI, Molina-Jijón E, AndéricaRomero AC, Tapia E, Pedraza-Chaverrí J. Renoprotective effect of the antioxidant curcumin: Recent findings. Redox Biol. 2013; 1(1): 448-456. 